\title{
CGB3 wt Allele
}

National Cancer Institute

\section{Source}

National Cancer Institute. CGB3 wt Allele. NCI Thesaurus. Code C52026.

Human CGB3 wild-type allele is located in the vicinity of $19 q 13.33$ and is approximately 26 $\mathrm{kb}$ in length. This allele, which encodes choriog onadotropin subunit beta protein, plays a role in gestation. The gene is essential for the production of steroids that are responsible for the maintenance of pregnancy. 